\title{
Toward a New Nigerian Womanhood: Woman as Nation in Half of a Yellow Sun
}

Jennifer Rideout

\section{(2) OpenEdition \\ 1 Journals}

Electronic version

URL: https://journals.openedition.org/ces/5213

DOI: $10.4000 /$ ces.5213

ISSN: 2534-6695

Publisher

SEPC (Société d'études des pays du Commonwealth)

\section{Printed version}

Date of publication: 1 April 2014

Number of pages: $71-81$

ISSN: 2270-0633

\section{Electronic reference}

Jennifer Rideout, "Toward a New Nigerian Womanhood: Woman as Nation in Half of a Yellow Sun", Commonwealth Essays and Studies [Online], 36.2 | 2014, Online since 15 April 2021, connection on 19 July 2021. URL: http://journals.openedition.org/ces/5213 ; DOI: https://doi.org/10.4000/ces.5213

\section{(c) $($ () $\ominus$}

Commonwealth Essays and Studies is licensed under a Licence Creative Commons Attribution - Pas d'Utilisation Commerciale - Pas de Modification 4.0 International. 


\section{Toward a New Nigerian Womanhood: Woman as Nation in Half of a Yellow Sun}

In Half of a Yellow Sun, Kainene, Mama, and Olanna define Nigeria's struggle for nationhood. I argue that Kainene represents the future and Mama, the traditions. As unacceptable extremes, the two are eliminated, leaving Olanna as the allegorical female symbol of nationhood. European-educated Olanna gets caught up in the Civil War, embodying both Kainene's bravery and Mama's traditional ways. By the end of the novel, she comes to represent the woman as nation in the new Nigeria.

Postcolonial scholarship about the Nigerian Civil War largely focuses on the victimization of civilians, especially that of women and children. Chimamanda Ngozi Adichie's Half of a Yellow Sun deals with issues of civilian survival during the Nigerian Civil War. ${ }^{1}$ She uses Olanna as the female allegorical symbol of the nation, juxtaposing her with her twin sister, Kainene - a strong, modern woman - and with Mama, another strong but custom-bound woman. Mama, Odenigbo's mother, disapproves of the live-in relationship her son has with Olanna. Each of these three female characters can be seen as embodying only part of the nationalist image of women - the modern or the traditional, respectively - rather than the whole image. A closer look at the events in the novel reveals that Adichie, whether she intended to or not, drew on modern Kainene and traditional Mama before eliminating them from the story, leaving Olanna as the pivotal character embodying both aspects. While Olanna's Western education marks her as an outsider, Adichie brings her back into the fold of Nigerian women as she adapts to gender-specific tasks, such as caring for children and cooking food in the refugee camps, while negotiating her outsider status within the changing boundaries of Nigerian womanhood. In "Third-World Literature in the Era of Multinational Capitalism," Frederic Jameson writes that "All third-world texts are necessarily, I want to argue, allegorical, and in a very specific way: they are to be read as what I will call national allegories, even when, or perhaps I should say, particularly when their forms develop out of predominantly western machineries of representation, such as the novel" (69). Thus, in Half of a Yellow Sun, Olanna becomes the female allegorical embodiment of the nation. ${ }^{2}$

Feminist readings of Olanna generally represent her as a strong female character. In "History and Ideology in Chimananda Adichie's Fiction," Sophia Ogwude proposes a feminist reading of the novel, writing that "the novel bustles with bold and successful full-bodied women with no inhibitions" (120). Reading Olanna through this "Western lens" reveals that she is from the middle class, well-educated at a foreign university, speaks multiple European languages, lives unwed with Odenigbo, accepts that she is unable to have children, and teaches at the university. Overall, she has a successful life.

1. Also known as the Nigerian-Biafran War (1967-1970), this three-year conflict arose from ethnic tensions between the Muslim Hausa-Fulani in the north and the Christian Igbo in the southeast. Fearing political domination by the Hausa-Fulani, the Igbo staged a coup d'état and seceded from Nigeria, becoming the Republic of Biafra. This prompted the animist Yoruba of the southwest to join with the Hausa-Fulani against the Igbo. The subsequent conflict resulted in deaths of over one million people, many of whom were Igbo civilians (Hurst).

2. Such allegorical representations of the nation characterize not only Nigerian writing (e.g., Chinua Achebe and Ben Okri), but also much of postcolonial literature (e.g., Salman Rushdie and Carlos Fuentes). 
However, through the progression of events in the novel, Olanna's Western lifestyle alters as she faces adversity together with fellow Igbo women and is influenced by these women whose roles are culturally defined by a nationalist vision of women. Deniz Kandiyoti explains what is generally meant by this:

On the one hand, nationalist movements invite women to participate more fully in collective life by interpolating them as "national" actors: mothers, educators, workers, and even fighters. On the other hand, they reaffirm the boundaries of culturally acceptable feminine conduct and exert pressure on women to articulate their gender interests within terms of reference set by nationalist discourse. (380)

Through the adversity of war, Olanna embodies the women's role of “'national' actor[s]" (380) by becoming an adoptive mother, educating small children in the refugee camps about their new country, The Republic of Biafra, working with the other women in the camps to provide food, and fighting for her family's survival.

Effa Attoe in "Women in the Development of Nigeria Since Pre-colonial Times" traces a timeline of Nigerian women's changing roles from the pre-colonial period, through British occupation, and into the post-colonial period. She reports that the roles of women in pre-colonial Nigeria changed significantly from those of strength and independence to marginalization under British control. Additionally, Oyèrónke Oyěwùmí explains in The Invention of Women: Making an African Sense of Western Gender Discourses that before British colonization "there were female chiefs and officials all over Yorubaland" (125) whose power was taken away by the British, who placed African men in those unaccustomed roles. According to Oyěwùmí, "the alienation of women from state structures was particularly devastating because the nature of the state itself was undergoing transformation [into a Western power structure]" (122). In changing both men's and women's roles, the British placed men in leadership positions they were not prepared to fulfil, and the women found themselves ultimately colonized by both, thus becoming confined to marginal domestic roles similar to those European women occupied. A journal excerpt included in The Invention of Women reads:

Mrs. Tremlett, a European woman who accompanied her husband to Nigeria during this period, lamented about the position of European women: "I often found myself reflecting rather bitterly on the insignificant position of a woman in what is practically a man's country. [...] If there is one spot on earth where a woman feels of no importance whatsoever, it is in Nigeria at the present day." (125)

Oyěwùmí attests that "if the women of the colonizer were so insignificant, then one could only imagine the position of the 'other' women, if their existence was acknowledged at all" (125). Attoe further reveals that during the British occupation, Nigerian women's roles were largely marginalized by the export economy that relied more on educating males and teaching domestic roles to females. Under the British, Nigerian women lost their active role in contributing to the community while retaining their role as wives and mothers. They were relegated to domesticity whereas the men were educated in a British system of values that reinforced a view of women as subordinates, resulting in the double-colonization of Nigerian women. Pre-colonial Nigerian women's involvement in commerce thus gave way to the Eurocentric model of a male-dominated commerce structure, invalidating the women's role in commerce. However, when the British left in 1960, Attoe explains that women resumed their roles in food production and subsistence. Later, in 1967, while the men were fighting the war, the women's roles 
became defined through the allegorical representation of women as sustainers and lifegivers of the nation. During the war, women were thrust into positions of nurturing, providing, and resuming some of their pre-colonial trader status in order to survive - all roles Kandiyoti also lists in her explanation of nationalist movements and all roles that Olanna embodies as representative of the woman as nation.

Before Olanna's transformation from Western woman to allegory can be examined, Kainene and Mama, who represent extreme and, therefore, partial nationalist models of women, must be explored. Jameson defines third-world allegorical literature, explaining that "all the telling of the individual story and the individual experience cannot but ultimately involve the whole laborious telling of the experience of collectivity itself" (85-6). In further examining Kainene and Mama, I will establish the characteristics that Adichie draws from each of them to create Olanna. Then I will show how, when Olanna finds herself in the refugee camp, the collective influence of fellow Nigerian women on Olanna rounds out Adichie's allegory. Adichie depicts Kainene as a powerful, independent, almost masculine woman, and thus, her anti-conservative ways go beyond formulaic construction of women. Adichie emphasizes Kainene's power through two relationships - her relationship with her lover Richard and the one she shares with her father. Richard is so intimidated by her that it renders him impotent in their early sexual relations. Adichie writes that "he had not permitted himself to hope for too much. Perhaps it was why an erection eluded him: the gelding mix of surprise and desire" (79). At their next encounter, Richard "was so terrified of failing her again that seeing himself erect made him deliriously grateful, so grateful that he was only just inside her before he felt that involuntary tremble that he could not stop" (80). His insecurity vis-à-vis Kainene is exacerbated by her inscrutability, since most of the time she is so indifferent and reserved compared to other women. In contrast, when he is with Kainene's sister Olanna, who is more feminine and thus closer to what he expects of a woman, he is not impotent during their single sexual encounter. When Olanna and Richard have sex:

She raised her hips moving with him, matching his thrusts, and it was as if she was throwing shackles off her wrists, extracting pins from her skin, freeing herself with the loud, loud cries that burst out of her mouth. Afterward, she felt filled with a sense of well-being, with something close to grace. (293)

In observing his own sexual response to Olanna, Richard finds that "he had never been so firm, never lasted so long as he had with her" (294). In her femininity, Olanna increases Richard's sense of masculinity. However, afterwards, Olanna and Richard both fear Kainene's anger, should she find out about their encounter.

Kainene's power is even stronger in her business relationships. Her father says of her: "she'll oversee everything in the east, the factories and our new oil interests. She has always had an excellent eye for business [...] Kainene is not just like a son, she is like two" (39). Nigerian historian Jacinta Chiamaka Nwaka explains that "the survival strategies adopted by Biafran women during the Civil War brought to the fore their untapped potential to contribute more [actively] in the economic and social spheres of society through their innovative abilities and business acumen" (45). Kainene's contribution to the well-being of the Nigerian women and children lies not in her working directly with them (as Olanna does in the refugee camps) but in her use of business acumen to work through the patriarchal system and meet with powerful male leaders, who are contacts she has made when working in her father's corporation. In this capacity, she gains access 
to food depots that are the domain of men and negotiates deals to benefit refugees in the relief camps. Nwaka's explanation of survival strategies fits with Kainene's role. Nwaka asserts that by showing that "as with war in general, the conflict in Biafra swept aside some cultural and gender-based traditions as women inherited men's responsibilities and ways of carrying them out. Survival took precedent" (45). Later in the novel, frustration with lack of food and flaws in the system that provides food to refugees results in Kainene's decision to go across enemy lines to get supplies - a strategy called afia attack. In "Igbo Women in the Nigerian-Biafran War 1967-1970: An Interplay of Control," Christie Achebe defines afia attack thus:

"Afia attack" [is] so called because its war-like nature mimics the military attack against an enemy stronghold. The shrinking of food sources during the war was a direct assault on the capability of the women to successfully carry out what they perceived as their traditional role. It was an attack that impugned their very reason for being - to oversee the health of the nation. This was a war of survival that was making a mockery of the women's self-worth and integrity and was threatening to strip them of their status in society. They had to modify their role to fit the new emergency. (11-2)

Unlike other women, Kainene does not have to modify her role as Achebe suggests. She has no apprehension about crossing enemy lines. Ever the businesswoman, she has a job to do, and she does it. Despite her independence and power, Kainene both literally and figuratively "crosses the line" when she goes on afia attacks. The word "attack [...] injects in a serious manner a kind of sarcasm, of playful aggression, which although intended as an effective method of behavioral control, simultaneously communicates the women's displeasure with Nigeria's aggression while keeping the lines of interaction open" (11-2). Literally crossing the line, the enemy line, Kainene vanishes (i.e., she never returns and is presumed dead). I would argue that, figuratively, she "crosses the line" of being too independent, which goes against the formulaic vision of women. Therefore, Kainene disappears from the story.

As a strong but conservative character, Mama too is removed from the story. Mama, the traditional Igbo woman, does not believe in education for women and is convinced that Olanna, with her Western education and teaching position at the university, is wrong for her son. She tells Ugwu: "too much schooling ruins a woman; everyone knows that. It gives a woman a big head and she will start to insult her husband. What kind of wife will that be?" (124) In her powerful role as matriarch, Mama brings the village girl Amala, her servant, with her to provide Odenigbo with a fertile mistress who can give her the grandson she desires. In reference to Amala's affair with Odenigbo, Adichie writes of Amala: "she had not said no to Odenigbo because she had not even considered that she could say no" (313). Amala thus represents the double-colonized woman who has no voice. She is dominated by the matriarch, Mama, and submits to the patriarchal figure, Odenigbo. Mama's choice of Amala contrasts sharply with her views about Olanna. She says to Olanna: "they say you did not suck your mother's breasts [...] Please go back and tell those who sent you that you did not find my son. Tell your fellow witches that you did not see him" (122). Such a superstitious statement comes as a shock to Westernized Olanna. Even Odenigbo's servant, Ugwu, is intimidated by Mama. During Mama’s brief stay at Odenigbo's house in Nsukka, Ugwu says that "the last thing he wanted now was for Mama to colonize his kitchen or use Olanna's favorite saucepan for her strong-smelling soup. He wished so much that she would just leave" (265). Ugwu has no power to 
force Mama out, nor can he express his concerns to Odenigbo without insulting him, or without risking disrespect towards Mama. Ugwu's description of Mama as colonizer is significant. Since Olanna lives unwed with Odenigbo, culturally, Mama does not have to respect her as the woman of the house in the same way that the naïve Ugwu respects her. Mama explains to Ugwu: "she is not your madam, my child. She is just a woman who is living with a man who has not paid her bride price" (265). In clinging to her custom-bound ideas, Mama exceeds the nationalist vision of women, just as Kainene does. Before long, she too is removed from the story when the future approaches her village in the form of Hausa soldiers. Mama hangs on to her home and ancestral folk ways, and therefore loses her life to troops who seek to advance a different cultural agenda. Between Kainene being too powerful a modern woman and Mama being too powerful a traditional woman to match the formulaic vision, the definition of woman as nation in the novel falls to Olanna.

While Kainene and Mama are constructed as powerful opposites (and therefore eventually eliminated from the story), Olanna brings together the ideal attributes of each woman - she becomes a mother like Mama; she herself is an educator, she works with the refugee women and their children; and she fights for the refugees and her own family as Kainene does. Earlier discussion of Kandiyoti's explanation of these roles as "pressuring women to articulate their gender interests within terms of reference of nationalist discourse" (380) creates a connection in the novel that cannot be overlooked, a connection between women fighting for survival and men fighting a war for Nigeria's survival. While the men fight to rebuild the nation, Susan Andrade credits Adichie with choosing to explore the Nigerian Civil War "through the tale of female twins who become estranged from each other" (93) and, through them, representing women's efforts in the making of the new nation. As pointed out earlier, women have historically been assigned a limited role in nationalist struggles and wars (Kandiyoti). War is a masculine activity, and the national ideal of women results from the masculine attitude to war. I would argue that just as Kainene and Mama represent opposite ends of the feminine spectrum - the modern and the traditional - in this allegory, so too does Nigeria's split parallel the division between these two women. The North looks to the future, concerned about the loss of wealth from the South if secession is successful, and the Igbo in the South secede because they find their ancestral way of life threatened by cultural, ethnic and religious differences with the North. The end of the war eventually brings together the divided country, mirroring the way in which Olanna brings together and embodies the strength and determination of Kainene and Mama, who represent respectively the modern and the traditional perspective. Olanna becomes more a Nigerian woman and less a Western woman as a result of her diverse experiences in trying to survive the war.

Olanna comes to represent the woman as nation through several life-changing events. The psychology behind Olanna's transformation is explained by Kandiyoti who writes:

Women participating in nationalist movements were $[. .$.$] prone to justify stepping out of$ their narrowly prescribed roles in the name of patriotism and self-sacrifice for the nation. Their activities, be they civic, charitable or political, could most easily be legitimized as natural extensions of their womanly nature and as a duty rather than a right. (379) 
Olanna's experiences feed into this impulse. For example, when she learns about Odenigbo and Amala's affair, Olanna finds the strength, despite her anger, to do what is right by the child as well as by the true victim of the affair, the double-colonized Amala. Having no voice in the situation, Amala cannot or will not fulfil her maternal role of feeding and caring for Baby, and Mama does not want the child because it is a girl. By drawing on Kainene's qualities of strength and independence, Olanna finds the power to overlook the affair and her own barrenness to accept motherhood, a traditional role that also creates a parallel between Olanna and Mama. Additionally, Olanna's decision to adopt Baby is taken independently of Odenigbo's vague postponing, and thus echoes Kainene's decisiveness and autonomy. Olanna says to Odenigbo, “We'll keep her' [...] Odenigbo turned to her with eyes widened behind his glasses [...] He looked tired. 'Let's think about this.' 'We'll keep her,' Olanna said firmly." (314) For Olanna, motherhood creates a direct connection with the next generation and becomes, as Kandiyoti explains, "a natural extension of [her] womanly nature" (379). Motherhood also invests Olanna more deeply with concern for the nation, since Baby will grow up to become a woman of Nigeria. As the events unfold in the novel, Olanna gains strength and power that permits her to see her and her family through. Donna Bailey Nurse asserts that Adichie "demonstrates with Olanna the way war can build - not merely erode - one's psychological constitution [...] a woman who changes in the war and not necessarily for the worse - finds strength" (27).

At only one point in the novel does Olanna seem to weaken, but even out of her weakness she finds the strength to face the challenges facing her during the war. While Olanna visits her ex-lover Mohammed in Kano, anti-Igbo riots break out. Adichie writes that "Mohammed went into a room and came out with a long scarf. "Wear this so you can blend in,' he said" (184). He fears for her safety if it becomes apparent that she is Igbo, and not a Muslim woman. She insists Mohammed take her to rescue her family members before she leaves the area. When Mohammed drives her to Sabon Gari to pick up her family, she finds her Uncle Mbaezi and Aunty Ifeka savagely slaughtered (186). In her article discussing civil wars in Africa, Ifeyinwa Maureen Ogbanna-Nwaogu studies the causes of sexual violence during the wars. In the novel, Adichie describes several acts of sexual violence committed by soldiers who split open women's pregnant bellies. Adichie implies that Arize has been a victim of such brutality when she writes, "Arize, she said. 'Arize is down the road" and one of the soldiers shouts "We finished the whole family" (186). Nwaogu explains that "soldiers [...] split open the bellies of pregnant women at roadblocks "to find hidden rebels"' (253). Stunned by the gruesome sight of her family's slaughter, Olanna has to be led back to the car by Mohammed. Adichie explains that "Mohammed pushed her into the car and then went around and got in. 'Keep your face down,' he said” (186). With Mohammed telling her to put on a scarf and keep her face down, Olanna experiences the patriarchal system in the North, a system she almost married into with Mohammed when she was younger. ${ }^{3}$ Olanna's

3. Mohammed's mother provides an image of what Olanna's life would have been had she married him. Visiting Kano and Mohammed's palace, Olanna describes his mother "with the ring in her nose and the silk scarves around her head. She was finespun in the way that used to make Olanna wonder if she wasn't uncomfortable, dressing up every day and simply sitting at home" (57). Later, Mohammed commands Olanna to wear a scarf as he rushes her to the train station, rescuing her from the rioters who are killing Igbos. Olanna "tugged at the scarf; the embroidery at the edges felt coarse and uncomfortable against her neck" (185). Ironically, the scarf, a symbol of patriarchal control that causes Olanna irritation and discomfort, becomes her means of escaping death. 
horrific experience intensifies when she boards a train with masses of people fleeing south. With the images of her slaughtered family members fresh in her mind, Olanna does not realize what the woman next to her actually has in her calabash. To her horror, "Olanna looked into the bowl. She saw the little girl's head with the ashy-gray skin and the braided hair and rolled-back eyes and open mouth. She stared at it for a while before she looked away. Somebody screamed" (188). Olanna continues to cope with these horrors until she gets home. Once she is safely home, her defences crumble:

Olanna's dark swoops began the day she came back from Kano, the day her legs failed. Her legs were fine when she climbed down from the train and she did not need to hold on to the blood-smeared railings; they were fine as she stood for the three-hour drive to Nsukka in a bus so crowded she could not reach out to scratch her itching back. (196)

The overwhelming experience of the horrors hits her, leaving her incapacitated on Odenigbo's front steps (196). She has to find the strength to get out of the North and endure the train ride to get home. However, from a psychological point of view, her arrival home results in the lowering of her defences, and Olanna loses the ability to function normally for a time. When her strength returns, Olanna still thinks of the trauma her family suffered, but she also becomes aware of the horrors she may have to face as the war continues to move towards her home.

Not only does Olanna find strength in herself, she also works with others living at the refugee camp to build their strength to survive. Before she can serve others in the refugee camp, Olanna has to learn how these camps function. Mrs. Muokelu helps Olanna negotiate the food depot on her first visit there. While jostling for a place in the food relief lines, she tells Olanna: "Join that one! [...] That is the egg yolk line! Join it! This one is stockfish" (336-37). Olanna, the confident Western woman, finds that Mrs. Muokelu and other subjugated Nigerian women have much to teach her. At first:

Olanna stood awkwardly among the men and women and children, who all seemed used to standing and waiting for a rusted iron gate to be opened so they could go in and be given food donated by foreign strangers. She felt discomfited. She felt as if she were doing something improper, unethical: expecting to get food in exchange for nothing. (335)

Obliged to shed her Western propriety, Olanna "joined the queue and held herself from pushing back at the woman who tried to nudge her out. She let the woman stand in front of her. The incongruity of queuing to beg for food made her feel uncomfortable, blemished" (337). Olanna finds herself in what is likely to be a situation she would previously never have imagined. Having grown up in a wealthy family, Olanna has never prepared food, much less begged for it. Realizing that she must beg for food, if she and her family are to have any, forces her to give up some of her Western, educated manners and become just another woman at the refugee camp. While at the refugee camp, Olanna learns to negotiate the food depot and cooks food for her family, a significant contrast to her life as a university professor immersed in her work while her servant, Ugwu, took care of domestic chores. Her nurturing role further develops in the refugee camp when she teaches the small children about the history of their new nation, Biafra. She tells Ugwu and Mrs. Muokelu, "We have to make sure that when the war is over, they will all fit back easily into regular school. We will teach them to speak perfect English and perfect Igbo, like His Excellency. We will teach them pride in our great nation" (366). Caring for fellow refugees and helping to educate the next generation demons- 
trates Olanna's development as an allegorical character contributing to the definition of a national ideal for Nigerian women.

Little does Olanna know that she will be called to care not just for the women and children, but also for Odenigbo whose strength she always admired. Olanna observed him at his family home in Abba: "walk[ing] across the veranda, aggressive confidence in his stride. Her man. Sometimes when she looked at him she felt gripped by proud possession" (233). Adichie works against the notion of war as a masculine activity involving strength and power by taking a male character, Odenigbo, whom Olanna has always viewed as strong and showing him through Kainene's eyes as weak. Early in the novel, Kainene sarcastically describes Odenigbo as Olanna's "revolutionary lover" (44). Kainene says of Odenigbo, "this Odenigbo imagines himself to be quite the freedom fighter. He's a mathematician but he spends all his time writing newspaper articles about his own brand of mishmash African socialism" (87). Such descriptions make Odenigbo sound more like a passive observer of those involved in real combat. Frantz Fanon explains the phenomenon of the educated native intellectual in his essay "On National Consciousness":

The native intellectual who comes back to his people by way of cultural achievements behaves and acts like a foreigner. Sometimes he has no hesitation in using a dialect in order to show his will to be as near as possible to the people; but the ideas that he expresses and the preoccupations he is taken up with have no common yardstick to measure the real situation which the men and the women of his country know. (41)

Kainene's perspective reveals Odenigbo's passivity and its contrast with Olanna's strength as the novel progresses. From the beginning of the book, Odenigbo's place in the war is on the sidelines. He holds meetings with other university professors in his home to discuss issues associated with the war. He writes articles, signs a petition, and later at the refugee camps joins some activist groups. However, he is never truly active in the war as a soldier, and is more akin to an observer. Perhaps Olanna's love for him colors her view of him and prevents her from seeing his limitations. Later in the book, when Odenigbo learns about his mother's death at the hands of the Hausa soldiers who invade her village, this, combined with his reduced living circumstances as a result of the war, leaves him a powerless drunk. Adichie writes: "but he no longer went into the interior with the Agitator Corps, no longer returned with lit-up eyes. Instead, he went to the Tanzania Bar every day and came back with a taciturn set of mouth" (404). When he crumbles, Olanna rises up to carry the family forward, showing a strength similar to Kainene's, but which includes caring and nurture, an embodiment of the new and the old. As a result of Odenigbo's breakdown, Olanna finds herself not only impacted by conservative and modern attitudes toward womanhood but also thrust into the masculine role of leading her family.

Olanna also adopts another masculine role, that of protector, when trying to keep Ugwu from getting conscripted. Just as Odenigbo weakens as the novel progresses, Ugwu also appears as a weak male character in his role as a servant, and, thus, a social inferior to Olanna and Odenigbo, having to defer to their wishes. However, when he is recovering after having been wounded in battle, Odenigbo and Olanna view him differently. Upon learning of Ugwu's whereabouts, Odenigbo and Olanna share the symbolic gesture of together "wrapping their arms around Ugwu, but lightly, without 
pressure, so as not to cause him any pain. He felt acutely uncomfortable; they had never hugged him before" (496). This gesture is significant for Ugwu:

Adichie's projections of her society are largely visionary. She goes beyond mirroring the contemporary Nigerian society in that in exposing our current existence, she emphasizes what we could become. Masters and houseboys relate as human beings and not as masters and slaves; the woman of the house does not need to be accepted by her mother-in-law or to prove her usefulness as a child-bearer before she can confidently take charge of her house. (Ogwude 122)

The gesture is also significant for Odenigbo and Olanna, because it places them once again on more equal terms. Just prior to this, we learn that Odenigbo has taken to drinking again at a bar nearby: "only last week, the bar owner had come to the house asking for him because he had not paid his balance" (488). However, Olanna has other worries and cannot worry about Odenigbo anymore (488). This chapter puts an end to Odenigbo's suffering when he and Olanna make love and "he was crying too; she felt the tears drop on her body before she saw them on his face. Later, he propped himself on his elbow and watched her. 'You're so strong, nkem"' (491). Odenigbo's admiration of Olanna's strength reveals recognition of his own weakness. When they bring Ugwu home together, their family reunites again, and healing begins for all three of them. Olanna can finally let go of the masculine role, because Odenigbo finds the strength to overcome his mother's death and focus on his family again. Beginning with the rescue of Ugwu, Odenigbo and Olanna function together as a married couple, a traditional construction but including a modern sense of equality that places them on more common ground than the conservative patriarchal marital structure focused on female submission. Embodying the new vision for women, Olanna balances her modern marriage with the more conservative nurturing role to which her being a woman predisposes her. In nursing Ugwu, "Olanna was always beside him, forcing him to eat and willing him to live" (497). Fulfilling this maternal role, Olanna cares for Ugwu while unknowingly preserving his life for the future of the nation. Little does she know at the time that she is in fact nursing back to health the writer who will tell the tale of the Nigerian Civil War. Joyce M. Chadya explains that "during the liberation struggles, nationalists played upon the patriarchal ideology of women as caregivers and nurturers, upholders of traditions and customs, reservoirs of culture, and as a result, nationalist propagators of mother politics" (153). However, representing woman as nation, Olanna reaffirms aspects of the patriarchal ideology by fulfilling a maternal role, but also goes beyond it by assuming responsibilities associated with a paternal figure of authority. She begins by adopting the motherhood role with Baby, furthering that role in the refugee camp, and assuming leadership in supporting the family when Odenigbo fails in his role. By going beyond the binary extremes of modern and traditional roles characterized by Kainene and Mama, Olanna redefines the nationalist depiction of women.

As a result, by the end of the novel, not only does Olanna shed some of her Western ways but, ironically, she adopts a more indigenous approach in her fight to find Kainene. This is ironic because Kainene represents the powerful, modern woman and, as such, would surely have scoffed at Olanna when she turns to superstition. Olanna requests traditional medicines from the dibia in her fight to find Kainene, an action which echoes Mama's seeking medicines from the dibia in her desperation for a grandson. Olanna asks her Uncle Osita to consult the dibia for her when the energy she needs 
to search for Kainene falters and she has to reach out to powers beyond herself in the hope of finding her sister (540). Having only known Olanna as a modern woman, Odenigbo questions her sudden belief in traditional medicines (540). However, by this point in the novel, Olanna has both modern and indigenous approaches to her life, just as postcolonial Nigeria wavers between the new and the old as the nation tries to find its own balance. Her last words in the novel show a changed Olanna: "I do believe in it. I believe in everything. I believe in anything that will bring my sister home" (540).

Just as Olanna draws from "everything," so the postcolonial definition of Nigerian womanhood draws from everything, traditional and modern, that reinforces feminine (and also human) solidarity. From British colonization in 1900 to independence in 1960, double-colonized Nigerian women found themselves to be outsiders in their own country. Just seven years into independence, Nigerians, working to define their nationhood, found themselves embroiled in the Civil War. Adichie seems to indicate in Half of a Yellow Sun that with the men fighting the war, Nigerian women, represented allegorically by Olanna, rediscover themselves through their struggle to survive and to preserve the next generation. Substantiating this vision, Jameson pronounces that "the story of the private individual destiny is always an allegory of the embattled situation of the public third-world culture and society" (69). While feminist readings of Half of a Yellow Sun interpret Olanna as a strong character, she finds her strength when the war slowly peels away her adherence to modern, Western ways, permitting her to combine modern with conservative ways, thus recreating her character, whether Adichie realized it or not, as a woman representative of the nation. Though Olanna speaks European languages, she wishes she knew more of the native languages to help her communicate with those around her. Her previous notion that marrying Odenigbo could damage their relationship disappears when the uncertainty of war makes her decide to commit to their future together through marriage. She becomes a mother despite her infertility, thus fulfilling the cultural role of motherhood that she previously thought closed to her. Additionally, Adichie keeps Olanna's position as a teacher at the university vague while emphasizing the importance of her work teaching the next generation of small children in the refugee camps. Though she had lived in Nigeria, Olanna's Western education and lifestyle allowed her to live a very different life outside the world of the average Nigerian woman. As a result of the Civil War, she finds herself for the first time inside the fold of Nigerian women. Only by "coming in" from "the outside" could Olanna, and by extension, Nigerian women, redefine womanhood in those changing times.

Jennifer RiDEOUT

Tennessee Tech University

\section{Works Cited}

Achebe, Christie. "Igbo Women in the Nigerian-Biafran War 1967-1970: An Interplay of Control." Journal of Black Studies 40.5 (2010): 785-811.

Adichie, Chimamanda Ngozi. Half of a Yellow Sun. New York: Anchor, 2006.

Andrade, Susan Z. "Adichie's Genealogies: National and Feminine Novels." Research in African Literatures 42.2 (2011): 91-101.

Аттое, S.A. Effah. "Women in the Development of Nigeria Since Pre-colonial Times." 9

November 2011. Onlinenigeria.com. <http://www.onlinenigeria.com/links/adv.asp?blurb=150>. 
Chadya, Joyce M. "Mother Politics: Anti-colonial Nationalism and the Woman Question in Africa." Journal of Women's History 15.3 (2003): 153-7.

FANON, Frantz. "On National Culture." 1961. Colonial Discourse and Post-Colonial Theory. Ed. Patrick Williams and Laura Chrisman. New York: Columbia UP, 1994. 36-52.

Hurst, Ryan. "Nigerian Civil War (1967-1970).” BlackPast.org. n.d. Web. 1 February 2014. <http:// www.blackpast.org/gah/nigerian-civil-war-1967-1970>.

Jameson, Fredric. "Third-World Literature in the Era of Multinational Capitalism." Social Text 15 (1986): 65-88.

Kandiyoti, Deniz. "Identity and its Discontents: Women and the Nation." Colonial Discourse and PostColonial Theory. Ed. Patrick Williams and Laura Chrisman. New York: Columbia UP, 1994. 376-91.

Nurse, Donna Bailey. What's a Black Critic to Do II: Interviews, Profiles, and Reviews of Black Writers. London, ON: Insomniac P, 2011.

NwakA, Jacinta Chiamaka. "Biafran Women and the Nigerian Civil War: Challenges and Survival Strategies." Africa Peace and Conflict Journal 4.1 (2011): 34-46.

Ogbonna-Nwaogu, Ifeyinwa Maureen. "Civil Wars in Africa: A Gender Perspective of the Cost on Women." Journal of Social Sciences 16.3 (2008): 251-8.

Ogwude, Sophia O. "History and Ideology in Chimamanda Adichie's Fiction." Tydskrif Vir Letterkunde 48.1 (2011): 110-2.

OYĔwùmí, Oyèrónke. The Invention of Women: Making an African Sense of Western Gender Discourses. Minneapolis: U of Minnesota P, 1997. 